\title{
International Fund on Child Protection and Roles of Local Government
}

\author{
N N Sirait ${ }^{1}$, Rosmalinda ${ }^{2}$ \\ ${ }^{1,2}$ Universitas Sumatera Utara, Medan, Indonesia \\ ${ }^{1}$ ningrum.sirait@gmail.com
}

\begin{abstract}
Convention on the right of the child (CRC) states the obligations of state party in article 4 which provides opportunities for state party such as Indonesia to have international cooperation. This paper figures out research results which conducted for 8 months in the Sumatera Utara province. The objective of the study was to determine the role of local government in the context of international fund for child protection program. There are three proposed questions concerning program, funding, and supervision including monitoring. In depth interviews and focus group discussion (FGD) involved local governments (OPDs) and agency for regional development (BAPPEDA). The study obtained information as follow: (a) Child protection programs performed by local government in collaboration with CSOs; (b) lack of international fund for Child protection managed by local government; and (c) supervision and monitoring are conducted internally or by up level of OPD. As recommendation, the local government needs to collaborate further with local CSOs in child protection including the program which supported by international fund(s).
\end{abstract}

Keywords: Governments, Child Protection, International Fund

\section{INTRODUCTION}

Convention on the right of the child (CRC) states in article 4 that every state party of CRC has the obligations to take all measures to fulfill child rights in its country [1].Thereare three obligations namely to respect, to protect and to fulfill rights which recognized in CRC [2]. Article4 also mentioned an important point concerning international cooperation between a state party such as Indonesia with others. The principles of international cooperation referred to articles 55 and 56 of the United Nations (UN) Charter namely equal rights and selfdeterminations of people [3].This international cooperation can be done through the elaboration of agreement, projects or programs taking a variety of forms, including technical assistance from UN agencies, bodies and organs, bilateral and multilateral aid treaties of aid and loans [3].

The United Nations Children's Fund (UNICEF) in its summary on child protection studies stated that the current legal and policy framework in Indonesia is conducive to promoting children's rights [4]. However, there are gaps such as disharmony between national and local regulations (Perda) in +500 districts. Every local government drafted its regulation without coordination. Due to this situation, the central government developed an approach known as 
Child Protection System (SPA). This approach has been developed in six provinces in the collaboration of Indonesian government and UNICEF [5].

Law No. 23 of 2014 concerning local government regulated child protection programs in line with Law No 23 of 2002 which amended by UU No 35 of 2014 concerning child protection. As mandated, Sumatera Utara province has a local regulation concerning implementation of child protection namely local regulation No. 3 of 2014 concerning implementation of child protection. This regulation must a reference for 33 district/cities in Sumatera Utara province.

This local regulation is a fact that Indonesia tries to fulfill its obligations as state party. It is also a measure of Indonesia to implement Sustainable Development Goals (SDGs). It addresses development issues including poverty which is a major factor of violation of children's rights [6]. Moreover, SDGs mentioned in number 17 about the partnership to achieve the objectives, strengthen the implementation and revitalize the global partnership for sustainable development [7]. This global partnership involves governments, donor agencies such as UN agencies as well as International Non-Government Organizations (OINP) and is not limited to information sharing but also financial support [6].

This research is intended to examine the role of local government on international fund for child protection program in Sumatera Utara Province.

There are 3 research questions concerning the implementation of child rights, namely:

1. What programs are undertaken by local government for child protection?

2. What international fund supported child protection programs of local government?

3. How does monitoring and supervision conduct for local government program?

\section{METHOD}

This research is a qualitative descriptive research. Data were obtained through literature review and field studies. The literature review used CRC, Law No. 23 of 2014 concerning local governments and Local Regulation No. 3 of 2014 concerning the implementation of child protection while the fields study involved 3 institution of local government.

\section{RESULT and DISCUSS}

\subsection{Child Protection Program}

Local regulation No. 3 of 2014 concerning the implementation of child protection, article 20 stated 12 OPD who are child protection providers in sumatera utara province such as:(a) empowerment of women, children and family planning office/Dinas P3A; (b) social welfare office/Dinsos, and (c) education offices/Disdik [8]. These OPDs do coordination to implement child rights through child friendly city program. For instance, there is a regulation of ministry of women's empowerment child protection number 13 of 2011 concerning guidance for developing child friendly city. Meanwhile, Disdik has inclusive education program as stated in governance regulation Number 29 of 2016 concerning implementation of inclusive education in Sumatera Utara province.

Interviews and FGDs found that Dinas P3A is the focal point for implementation of child protection in Sumatera Utara. It is in line with the main duties and functions of Dinas P3A in governor regulation no. 13 of 2017 concerning tasks, functions, job descriptions and work procedures. In conducting programs, Dinas P3A refer to local regulation No.3 of 2014 
concerning implementation of child protection and Law No.23 of 2014 concerning local governments which provides authority for Dinas P3A to conduct child protection program.

Table 1. List of Assigned Program between Central, Province and District Government based on Law No. 23 of 2014 Concerning Local Government.

\begin{tabular}{|c|c|c|c|c|}
\hline No & $\begin{array}{c}\text { Sub } \\
\text { Affairs }\end{array}$ & Central Government & Provincial government & District government \\
\hline 1 & $\begin{array}{l}\text { Family } \\
\text { Quality }\end{array}$ & $\begin{array}{l}\text { a. Improving the quality of } \\
\text { family in realizing gender } \\
\text { equality (KG) and child } \\
\text { rights at national level. } \\
\text { b. Strengthening and } \\
\text { developing institutions } \\
\text { providing quality family } \\
\text { service providers in } \\
\text { realizing KG and child } \\
\text { rights at the national level. } \\
\text { c. Standardization of service } \\
\text { providers to improve family } \\
\text { quality in realizing KG and } \\
\text { child rights. }\end{array}$ & $\begin{array}{l}\text { a. Improving the quality of family } \\
\text { in realizing gender equality (KG) } \\
\text { and child rights at provincial and } \\
\text { inter-district / municipal level. } \\
\text { b. Strengthening and developing } \\
\text { institutions providing quality } \\
\text { family service providers in } \\
\text { realizing KG and rights of } \\
\text { children whose working areas } \\
\text { are across districts / } \\
\text { municipalities. } \\
\text { c. Provision of services for families } \\
\text { in realizing KG and the right to } \\
\text { work in cross-border Regions / } \\
\text { municipalities. }\end{array}$ & $\begin{array}{l}\text { a. Improving the quality of } \\
\text { family in realizing gender } \\
\text { equality (KG) and child } \\
\text { rights at regency / city level } \\
\text { b. Strengthening and } \\
\text { developing institution of } \\
\text { service provider of family } \\
\text { quality improvement in } \\
\text { realizing KG and rights of } \\
\text { child whose working area is } \\
\text { in regency / municipality. } \\
\text { c. Provision of services for } \\
\text { families in realizing KG and } \\
\text { the rights of children whose } \\
\text { territory is within the } \\
\text { districts / municipalities. }\end{array}$ \\
\hline 2 & $\begin{array}{l}\text { Fulfillment } \\
\text { of Child } \\
\text { rights }\end{array}$ & $\begin{array}{l}\text { a. Institutionalization of PHA } \\
\text { in government, } \\
\text { nongovernmental, and } \\
\text { business entities at the } \\
\text { national level. } \\
\text { b. Strengthening and } \\
\text { developing institutions of } \\
\text { service providers to improve } \\
\text { the quality of life of children } \\
\text { at the national level. }\end{array}$ & $\begin{array}{l}\text { a. Institutionalization of PHA in } \\
\text { governmental, non- } \\
\text { governmental, and business } \\
\text { entities at provincial level. } \\
\text { b. Strengthening and development } \\
\text { of service providers to improve } \\
\text { the quality of life of children at } \\
\text { provincial and inter-district } \\
\text { levels. }\end{array}$ & $\begin{array}{l}\text { a. Institutionalization of PHA } \\
\text { to governmental, non- } \\
\text { governmental, and business } \\
\text { entities at district / city level. } \\
\text { b. Strengthening and } \\
\text { development of service } \\
\text { providers to improve the } \\
\text { quality of life of children at } \\
\text { district / municipality level. }\end{array}$ \\
\hline 3 & $\begin{array}{l}\text { Special } \\
\text { child } \\
\text { protection }\end{array}$ & $\begin{array}{l}\text { a. Prevention of violence } \\
\text { against children involving } \\
\text { national and cross-regional } \\
\text { authorities. } \\
\text { b. Provision of services for } \\
\text { children in need of special } \\
\text { protection requiring national } \\
\text { and international } \\
\text { coordination. } \\
\text { c. Strengthening and } \\
\text { development of service } \\
\text { provider institutions for } \\
\text { children requiring special } \\
\text { protection at national and } \\
\text { inter-provincial levels. }\end{array}$ & $\begin{array}{l}\text { a. Prevention of violence against } \\
\text { children that involves the parties } \\
\text { of the scope of the Provincial } \\
\text { Region and across the Regions / } \\
\text { municipalities. } \\
\text { b.Provision of services for children } \\
\text { requiring special protection that } \\
\text { requires provincial level } \\
\text { coordination. } \\
\text { c. Strengthening and development } \\
\text { of service providers for children } \\
\text { who need special protection at } \\
\text { the provincial and district levels. }\end{array}$ & $\begin{array}{l}\text { a. Prevention of violence } \\
\text { against children involving } \\
\text { stakeholders in regencies / } \\
\text { municipalities. } \\
\text { b. Provision of services for } \\
\text { children requiring special } \\
\text { protection that requires } \\
\text { coordination at the district } \\
\text { level. } \\
\text { c. Strengthening and } \\
\text { development of service } \\
\text { provider institutions for } \\
\text { children who need special } \\
\text { protection at district / city } \\
\text { level. }\end{array}$ \\
\hline
\end{tabular}




\subsection{International Fund for Child Protection}

According to local regulation No 3 year 2014 concerning the implementation of child protection, the fund of the program is from (a) the state budget (APBDN); (b) local government budget (APBD) and (c) other sources of legitimate and non-binding funds.

Field study obtained information which appropriate with article 25 of local regulation No.3 of 2014 concerning the implementation of child protection. Dinas P3A mentioned that child protection programs conducted by OPD are fully supported by APBN and APBD. It never accessedinternational fund as stated in article 25paragraphs (c). If there are international funds, the fundsare managed by CSOs. OPDs work together with CSOs in providing child protections services for instance in trafficking cases. Actually, there is a possibility for local government to access international fund directly through Local Technical Implementation Unit (UPTD) of Center for Women and Children Empowerment (P2TP2A). UPTD P2TP2A is a unit under Dinas P3A which is potential to access international fund for child protection. However, it is difficult for Dinas P3A to access international funds due to long bureaucracy. This finding is similar with Indonesian NGOs statement. They stated that bureaucratic in Indonesia is a complicated issue [6].

Furthermore, the study found that Dinsos, in 2016, has supported by International Organization for Migration (IOM) to provide services for unaccompanied minor irregular migrant. They are transported to Medan after stayed temporarily in Aceh [9].Dinsos was supported by IOM to provide shelter and daily need for the unaccompanied minor. However, Indonesia does not ratify the refugee convention [10]. Based on the informant, this status contributed complicated position for local government since the program managed by special unit not available unit such as children and elderly unit.

Although it is complicated for children as irregular migrants, cooperation in term of support from international fund in child protection program is possible. Law No. 23 of 2014 concerning local governance stated in the provision of services for children requiring special protection that requires coordination at national and international levels. Unfortunately, according to the informants, Dinsos faced challenges in accessing international funds for child protection programs. The challenges are lack of ability and skill to access international funding for instance language and drafting program proposal skills.

\subsection{Supervision and Monitoring}

Law No. 23 of 2014 concerning local Government, Article 1 Sub-Article 46 states that the Government's Internal Supervisory Apparatus is the ministry's inspectorate general, a nonministerial government agency supervisory unit, a provincial inspectorate, and a district / city inspectorate.

Local regulation No. 3 of 2014 on state administration, article 26 paragraph (1) states that the supervision of child protection is carried out by the provincial government supervisory agency and the Indonesian Child Protection Commission (KPAD) of Sumatera Utara province. However, since early 2017, KPAD is inactive. Chief of Dinas P3A mentioned it and published in an online newspaper in Medan [11].

Based on the research findings, Dinas P3A mentioned that it coordinates directly to the Ministry of Women Empowerment through technical coordination meeting. "... if women's 
empowerment and child protection, it is built that, all of Indonesia has the same spirit that must be synchronized, from the center of town to the city" (interview on $21^{\text {st }}$ May 2018).

\section{CONCLUSION}

The conclusions of this paper are (a) child protection programs conducted by technical OPDs in collaboration with CSOs; (b) Child protection funding in regions is dominated by APBN and APBD and (c) supervision and accountability are carried out under the funding scheme used. Furthermore, local governments have an important role in child protection programs in the region including programs that receive international funding support. However, local governments have limited access to and manage international funds. This limitation is due to the long bureaucracy, limited authority and human resources capability that must be developed.

We would like to thank the Research and Service Institute of University of Sumatera Utara who supported the authors to implement research program through TALENTA research scheme of Fiscal Year 2018 based on the Rector Letter Number: 433 / UN5.1. R / SK / PPM / 2018.

\section{REFERENCES}

[1] CRC, "Convention on the right of the child," United Nations High Commissioner for Human Rights (OHCHR), $1989 . \quad$ [Online]. Available: https://www.ohchr.org/en/professionalinterest/pages/crc.aspx.

[2] UNICEF, General Comments of the Committee on the Rights of the Child A Compendium for child rights advocates, scholars and policy makersp. Pretoria: UNICEF, 2014.

[3] M. Rishmawi, Article 4: the nature of states parties' obligations. Leiden: Martinus Nijhoff Publishers, 2006.

[4] UNICEF, "Ringkasan kajian perlindungan anak," UNICEF Indonesia, 2012. [Online]. Available: https://batukarinfo.com/system/files/A7 - B Ringkasan Kajian Perlindungan Anak.pdf.

[5] UNICEF, "Issue brief, the significance of child protection systems: key findings from a strategic mapping exercise in six provinces of Indonesia," UNICEF, 2011. [Online]. Available: https://www.unicef.org/indonesia/Issue_Brief_CP_Systems_Mapping_in_Indonesia.p df.

[6] YP2SU, "Menilik Efektifitas Peran Lembaga Donor dalam Pembangunan Manusia," 2017. [Online]. Available: https://ppsdm.id/menilik-efektifitas-peran-lembaga-donordalam-pembangunan-manusia/.

[7] I. Ishatono and S. T. Raharjo, "SUSTAINABLE DEVELOPMENT GOALS (SDGs) DAN PENGENTASAN KEMISKINAN," Share Soc. Work J., vol. 6, no. 2, p. 159, Dec. 2016.

[8] Regulation of the North Sumatera Province No 3 Year 2014 about child protection implementation. .

[9] UN High Commissioner for Refugees (UNHCR), "Response to the Rohingya Situation in Aceh and North Sumatera," UN High Commissioner for Refugees (UNHCR),

2016.

[Online].

Available: 
https://www.refworld.org/docid/58208e224.html.

[10] L. R. Briskman and L. I. Fiske, "Asylum seekers and refugees in Indonesia: Problems and potentials," Cosmop. Civ. Soc. An Interdiscip. J., vol. 8, no. 2, pp. 22-42, Jul. 2016.

[11] Berita Sumut, "Nasib KPAID Sumut Tunggu Evaluasi KPAI Pusat dan Depdagri," Berita Sumut, 2017. [Online]. Available: http://beritasumut.com/politikpemerintahan/Nasib-KPAID-Sumut-Tunggu-Evaluasi-KPAI-Pusat-dan-Depdagri. 